\title{
Sedimentation and Thermal Stratification During Floods: A Case Study on Hail Haor of North-East Bangladesh
}

\author{
M. Shahjahan Mondal ${ }^{1}$,Yuichi Kouchi ${ }^{2}$, and Kenji Okubo ${ }^{3}$ \\ ${ }^{1}$ Associate Professor, Institute of Water and Flood Management, Bangladesh University of \\ Engineering and Technology, Dhaka-1000, Bangladesh \\ Email: mshahjahanmondal@iwfm.buet.ac.bd \\ ${ }^{2}$ Researcher, Energia Economic and Technical Research Institute, The Chugoku Electric Power \\ Company, Inc., Hiroshima 739-0046, Japan \\ ${ }^{3}$ Professor, Graduate School of Environmental Science, Okayama University, Okayama 700-8530, Japan
}

\begin{abstract}
The presence of numerous haors (seasonal lakes), and the occurrence of flash floods and sedimentation are among the dominant physical and hydro-climatic features of North-East Bangladesh. These features for one of the haors (Hail Haor) in the region are studied using a conceptual hydrological model and a hydraulic routine. The hydrologic model used for daily runoff estimation from rainfall and evaporation information is the widely used tank model. Both soil-moisture movement and stream-flow routing are considered in the developed model. The tank runoff is used as an input to a hydraulic routine for estimation of stream water temperatures and suspended sediment load. Based on the stream sediment concentration, sedimentation in a downstream lake (Hail Haor) is estimated and it is found to be about $25 \mathrm{~mm}$ per annum. The relationship between monsoonal flooding and thermal response of the haor is investigated with one-year measured data of haor temperatures and water level. Different heat fluxes and thermal stability parameters are also estimated. The advection flux and the Richardson number are found to be sensitive to flooding in the haor. The unique feature of the Hail Haor found in the context of lake ecology is that thermal stratification occurs during sunny days under calm weather and complete mixing occurs in the event of large flash floods.
\end{abstract}

Keywords: tankmodel, suspended sediment, water temperature, thermal stratification, buoyancy flux, Richardson number, and haor.

\section{INTRODUCTION}

North-East Bangladesh is characterized by the presence of numerous large, bowl-shaped floodplain depressions, known as haors. There are about 47 major haors with a total area of about $8000 \mathrm{~km}^{2}$ in the region. The haors are important habitats for migratory winter birds and some rare species of aquatic flora and fauna. Numerous rivers rising in the hills of India supply water to the haors during the monsoon season. The extreme flashy character of the rivers and higher monsoonal rainfall in the region compared with other parts of the country cause frequent flash floods in the haors. The area of inundation ranges from $8000 \mathrm{~km}^{2}$ in 1986 to 10000 $\mathrm{km}^{2}$ in 1988, while the flood volume is about 15-35 $\mathrm{km}^{3}$ with an average depth of inundation of 2-3 m (Okubo, 1997). The flood water is highly turbid and the sediments get deposited on the haor bottom due to dense vegetation. This process of sedimentation is reducing the storage capacity of the haors and poses a threat to their mere existence in the future. We studied such sedimentation in the case of Hail Haor (Figure 1) using a combined hydrologic and hydraulic modeling approach. The hydrologic model used is the popular tank model 
for runoff simulation from rainfall and evapotranspiration inputs, and the hydraulic routine is based on the regime theory and resistance laws. The hydraulic routine uses the tank model output, i.e. river discharge, as its input.

The haor ecosystem experiences two alternate hydro-meteorological forcings from flash floods and calm and sunny weather. In the event of large flash floods, the haor water gets mixed and nutrients and oxygen exchanges occur between different water layers. This happens about 4-6 times a year and is good for ecological health and diversity. Between the two successive flash floods, thermal stratification occurs in the haors when calm wind condition and sunny days prevail.
Stratification is due to the buoyancy stock, which works as the potential energy (stabilizer) in the haor. Advection flux of momentum due to flash floods, or negative buoyancy of sediment, is the kinetic energy which destroys stratification. The ratio of these two in non-dimensional form is a sort of Richardson number. We studied the thermal stratification in the Hail haor in relation to flash floods and evaluated different fluxes and the stability parameter.

\section{TANK MODEL FOR SIMULATION OF DISCHARGE}

The tank model (Sugawara, 1979, 1995; Sugawara et al., 1984) is a lumped, conceptual model, in which a watershed is considered as a cascade of several

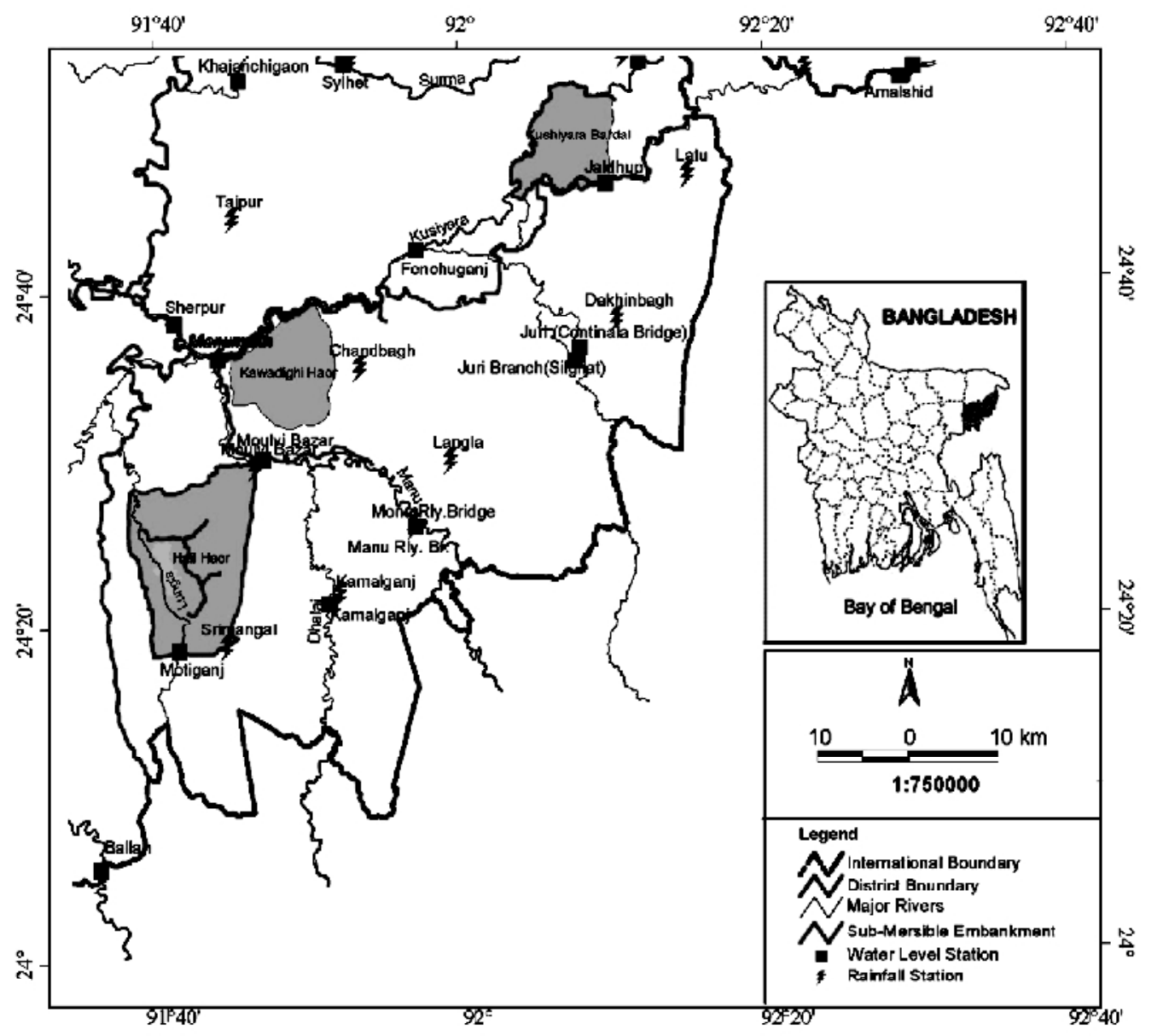

Figure 1: Map showing the Hail Haor and the Lungla River in Moulivibazar District of North-East Bangladesh 
vertical tanks. The model is built primarily on the concept of a linear reservoir. A number of forms of this model have been reported in the literatures and the model has been widely applied all over the world for simulation of rainfall-runoff, estimation of sediment yield and modeling of water quality (Mizumura, 1995; Kato, 2005; Lee and Singh, 2005; Paik et al., 2005; Huang et al., 2007). A layout of the tank model with three tanks is shown in Figure 2. The storage of the top tank is attributed to rainfall and evapotranspiration. The storages of the middle and bottom tanks are attributed to the percolation from the top and middle tanks, respectively. The storage of each tank is discharged through the side outlet(s) and bottom outlet except the bottom tank which has no bottom outlet. Each tank represents a particular runoff component of streamflow - the top, middle and bottom tanks with surface runoff, interflow and baseflow, respectively.

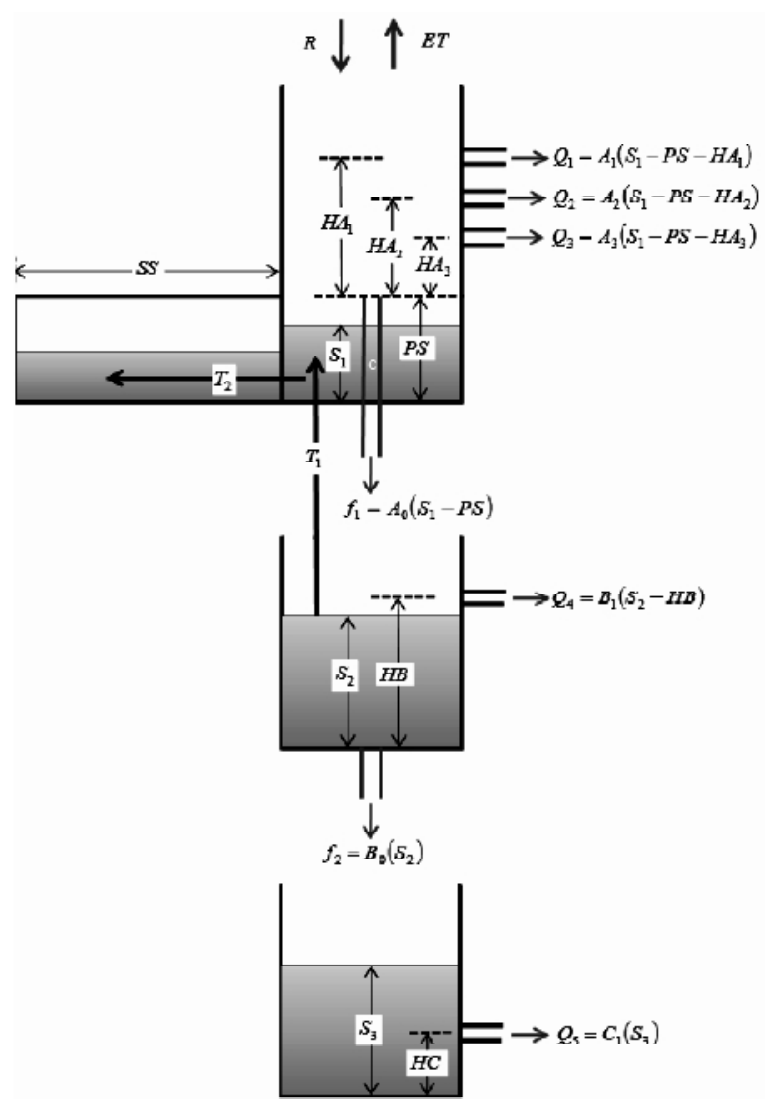

Figure 2: Tank model structure with soil-moisture component (routing tank is not shown)

Journal of Hydrology and Meteorology, Vol.6, No. 1
In Figure 2, $\mathrm{HA}_{1}, \mathrm{HA}_{2}, \mathrm{HA}_{3}, \mathrm{HB}$ and $\mathrm{HC}$ are the heights of side outlets; $A_{1}, A_{2}, A_{3}, B_{1}$ and $C_{1}$ are the runoff coefficients; and $\mathrm{A}_{0}$ and $\mathrm{B}_{0}$ are the percolation coefficients. The runoff, infiltration and percolation coefficients have units of time inverse. It is to be noted that these coefficients are the reciprocals of the storage coefficients (delay time constants) of a linear reservoir model. The tank model operates on two basic principles:

(a) The rate of runoff $(\mathrm{Q})$ through an outlet is proportional to the water head over that outlet; the rate of percolation $\left(f_{1}\right)$ from the top tank is proportional to the free water available in the tank; and the rate of percolation $\left(\mathrm{f}_{2}\right)$ from the middle tank is proportional to the available storage in the tank. The basis of this principle lies in experimental results.

(b) The principle of conservation of water volume for each tank.

Data on rainfall, evapotranspiration, runoff, watershed drainage area, etc., are necessary for the calibration of the tank model. The calibration technique is such that the initial runoff and percolation from each tank are estimated first for a given storage in the tank. Total runoff is then computed by summing up individual runoffs and multiplying with the watershed area. From the initial storage, runoff and percolation, and from the rainfall and evapotranspiration of the following time period, the storage of each tank is estimated for the next time period using the volume balance technique. From the resulting storage, runoff is calculated. This process of storage and runoff computation is repeated until the last time period of available data. All these steps yield residuals and hence the sum of squared residuals corresponding to the preliminary set of parameters. The final set of parameters is obtained by minimizing the sum of squared residuals using a non-linear least squares computer program.

In Bangladesh, there are two distinct climatic seasons: monsoon (June-October) and dry (November-May). In the dry season, there is little rainfall, particularly during the winter (November-

SOHAM-Nepal 
February). The moisture in the top soil frequently falls below the field capacity. During this period, an upward movement of soil water may occur from subsoil to topsoil depending on the relative dryness of the topsoil. Also, within a soil layer, water may move from the wet to the dry moisture zone. To account for this phenomenon, the top tank is further divided into two sub-tanks with primary and secondary soil moisture storages. This modification is necessary to avoid the criticism extended to another form of the tank model for the model's unidirectional water movement mechanism (Franchini and Pacciani, 1991). This modification increases the tank model parameters by six. The upward movement of moisture from the middle tank to the top tank is given by:

$T_{1}=T B\left(1-\frac{X P}{P S}\right)$

where, $\mathrm{XP}=$ actual water content of the primary sub-tank, PS = saturation capacity of the primary sub-tank and $\mathrm{TB}=$ a coefficient to be estimated during calibration. The upward flow of moisture continues as long as the primary sub-tank is unsaturated and provided that the middle tank has free water. The moisture exchange between the two sub-tanks is governed by the equation:

$T_{2}=T C\left(\frac{X P}{P S}-\frac{X S}{S S}\right)$

where, $X S=$ actual water content of the secondary sub-tank, SS = saturation capacity of the secondary sub-tank and TC $=$ a coefficient to be estimated during calibration. $\frac{X P}{P S}$ and $\frac{X S}{S S}$ denote the relative humidity in the primary and secondary sub-tanks, respectively. $T_{2}$ can be positive or negative. If it is positive, water transfers from the primary sub-tank to the secondary one and vice versa.

The hydrologic response of a watershed depends largely on its land and channel characteristics. With the traverse of a river from its source in the mountains to its outlet in a sea, ocean or floodplain, the dominance of the land phase decreases with the decrease in watershed elevation, slope, overland flow, etc., and that of channel phase increases with the increase in channel storages. To take into account the effect of channel storage on streamflow hydrograph, the overland flow from the top tank and the interflow from the middle tank are routed using an additional tank in series. This routing tank has a side outlet with a height of HD and a discharge coefficient of $D_{1}$. Further details of the tank model can be found in Sugawara et al. (1984).

\section{HYDRAULIC ROUTINE FOR SIMULATION OF STREAM TEMPERATURE AND SEDIMENT YIELD}

\subsection{STREAM TEMPERATURE}

Using the discharge output of the tank model as an input to a hydraulic routine, which is based on regime theory and resistance laws, the water depth $(h)$ and velocity $(u)$ can be obtained. The evaluation of stream water temperature can then be carried out with the following equation:

$T_{x}=T_{\theta}+\left(T_{0}-T_{\theta}\right) \exp \left(-\frac{k x}{c \rho u h}\right)$

where, $T_{0}=$ water temperature at a upstream section of a stream, $T_{x}=$ water temperature at a distance $\mathrm{x}$ downstream, $\mathrm{T}_{\mathrm{e}}$ equilibrium temperature, $\mathrm{k}=$ surface heat exchange coefficient, $\mathrm{c}=4190 \mathrm{Jkg}^{-}$ ${ }^{1} \mathrm{~K}^{-1}$ is the specific heat of water at constant pressure and $p=$ water density.

\subsection{SEDIMENT LOAD}

The vertical equilibrium Rouse profile, which combines logarithmic velocity profile and parabolic diffusion coefficient, for suspended sediment concentration of $\mathrm{C}$ with a median diameter of $\mathrm{D}$ is given by:

$\frac{c}{c_{b}}=\left(\frac{h-y}{h-a} \frac{a}{y}\right)^{z}$

where, $z=$ Rouse parameter. The possible maximum concentration $\left(C_{b}\right)$ of muddy material 
at a lake bed can be approximated by (Celik and Rodi, 1985):

$C_{b}=0.034 \frac{u_{*}^{2}}{\sigma g h} \frac{u}{w_{s}}$

where, $\sigma=1.65$ is submerged specific weight and $w_{s}=$ settling velocity of sediment. The suspended load obtained by the equation (4) was considered to be entirely contributing to the haor.

The expression for $w_{s}$ is:

$w_{s}=\frac{\sigma g D^{2}}{18 v}$

where $v=$ kinematic viscosity. The Rouse parameter $z$ is computed from the equations:

$z=\frac{w_{s}}{\beta \kappa u_{*}} \quad$ with $\quad \beta=1+k_{1}\left(\frac{w_{s}}{u_{*}}\right)^{k_{2}}$

where, $\mathrm{k}_{1}=1.54$ and $\mathrm{k}_{2}=2.12$ have been suggested by Kerssens et al. (1979) and $\mathrm{k}_{1}=1.56$ and $\mathrm{k}_{2}=2.0$ by Tsujimoto (1986). The total sediment load is computed by integrating $C$ in equation (4) over the water depth.

\section{SIMULATION RESULTS AND DISCUSSION}

\subsection{STREAM FLOW HYDROGRAPH}

We applied the above Tank Model to simulate the daily discharge of the Lungla River at Motiganj, which is located at the entrance of the Hail Haor (Figure 1). The river originates in the Indian State of Tripura and enters North-East Bangladesh through Srimangal Upazila of Moulvi Bazar District. It has a watershed area of about $610 \mathrm{~km}^{2}$ and a length of $45 \mathrm{~km}$. The river is flashy in its hydrologic behavior. The discharge data for model calibration and validation were collected since March 1988 from the Bangladesh Water Development Board (BWDB), Dhaka. The rainfall and pan evaporation data of Srimangal were also collected from the BWDB and the Bangladesh Meteorological Department, respectively.

Journal of Hydrology and Meteorology, Vol.6, No. 1
Table 1: Estimated values of the parameters of the calibrated tank model

\begin{tabular}{|c|c|c|c|}
\hline Tank & $\begin{array}{c}\text { Type of } \\
\text { parameter }\end{array}$ & $\begin{array}{l}\text { Para- } \\
\text { meter }\end{array}$ & $\begin{array}{l}\text { Value of } \\
\text { parameter }\end{array}$ \\
\hline \multirow[t]{8}{*}{ Top tank } & \multirow{3}{*}{$\begin{array}{l}\text { Runoff } \\
\text { coefficients }\end{array}$} & $A_{1}$ & $0.04\left(\right.$ day $\left.^{-1}\right)$ \\
\hline & & $A_{2}$ & $0.03\left(\right.$ day $\left.^{-1}\right)$ \\
\hline & & $A_{3}$ & 0.016 (day $\left.^{-1}\right)$ \\
\hline & $\begin{array}{l}\text { Percolation } \\
\text { coefficient }\end{array}$ & $A_{0}$ & $0.382\left(\right.$ day $\left.^{-1}\right)$ \\
\hline & \multirow{3}{*}{$\begin{array}{l}\text { Height of side } \\
\text { outlets }\end{array}$} & $H A_{1}$ & $15(\mathrm{~mm})$ \\
\hline & & $H A_{2}$ & $5(\mathrm{~mm})$ \\
\hline & & $H A_{3}$ & $0(\mathrm{~mm})$ \\
\hline & Initial storage & $S_{1}$ & $30(\mathrm{~mm})$ \\
\hline \multirow[t]{4}{*}{$\begin{array}{l}\text { Middle } \\
\text { tank }\end{array}$} & $\begin{array}{l}\text { Runoff } \\
\text { coefficient }\end{array}$ & $B_{1}$ & $0.0014\left(\right.$ day $\left.^{-1}\right)$ \\
\hline & $\begin{array}{l}\text { Percolation } \\
\text { coefficient }\end{array}$ & $B_{0}$ & $0.0168\left(\right.$ day $\left.^{-1}\right)$ \\
\hline & $\begin{array}{l}\text { Height of side } \\
\text { outlet }\end{array}$ & $H B$ & $0(\mathrm{~mm})$ \\
\hline & Initial storage & $S_{2}$ & $41(\mathrm{~mm})$ \\
\hline \multirow[t]{3}{*}{$\begin{array}{l}\text { Bottom } \\
\text { tank }\end{array}$} & $\begin{array}{l}\text { Runoff } \\
\text { coefficient }\end{array}$ & $C_{1}$ & $\begin{array}{l}1.4 \times 10^{-4} \text { (day } \\
\text { 1) }\end{array}$ \\
\hline & $\begin{array}{l}\text { Height of side } \\
\text { outlet }\end{array}$ & $H C$ & $0(\mathrm{~mm})$ \\
\hline & Initial storage & $\mathrm{S}_{3}$ & $0(\mathrm{~mm})$ \\
\hline \multirow[t]{3}{*}{$\begin{array}{l}\text { Primary } \\
\text { sub-tank }\end{array}$} & $\begin{array}{l}\text { Saturation } \\
\text { capacity }\end{array}$ & $P S$ & $50(\mathrm{~mm})$ \\
\hline & Initial storage & $X P$ & $30(\mathrm{~mm})$ \\
\hline & $\begin{array}{l}\text { Transfer } \\
\text { coefficient }\end{array}$ & $T B$ & $0.1\left(\mathrm{~mm} \mathrm{day}^{-1}\right)$ \\
\hline \multirow[t]{3}{*}{$\begin{array}{l}\text { Secondary } \\
\text { sub-tank }\end{array}$} & $\begin{array}{l}\text { Saturation } \\
\text { capacity }\end{array}$ & SS & $250(\mathrm{~mm})$ \\
\hline & Initial storage & $X S$ & $0(\mathrm{~mm})$ \\
\hline & $\begin{array}{l}\text { Transfer } \\
\text { coefficient }\end{array}$ & $T C$ & $0.1\left(\mathrm{~mm} \mathrm{day}^{-1}\right)$ \\
\hline \multirow[t]{3}{*}{$\begin{array}{l}\text { Routing } \\
\text { tank }\end{array}$} & $\begin{array}{l}\text { Runoff } \\
\text { coefficient }\end{array}$ & $D_{1}$ & $0.079\left(\right.$ day $\left.^{-1}\right)$ \\
\hline & $\begin{array}{l}\text { Height of side } \\
\text { outlet }\end{array}$ & $H D$ & $0(\mathrm{~mm})$ \\
\hline & Initial storage & $S_{4}$ & $0(\mathrm{~mm})$ \\
\hline
\end{tabular}

The parameters of the calibrated tank model are given in Table 1. The values of the parameters have similarity with the values of the tank parameters reported in Nagasaka and Nakamura (1999) for Toikanbetsu watershed in Japan. This Japanese watershed consists of floodplains, terraces and hills with predominant land uses of forest and grassland 
which have some degree of similarity with the Lungla catchment landscapes and land uses. The discharge hydrograph obtained from the model along with the observed hydrograph for the year of 1988 is shown in Figure 3. 1988 is the second largest flood year in the history of Bangladesh after the 1998 flood. It is seen from the figure that the calibrated tank model follows the observed discharge pattern reasonably well even during this huge flood year. The root mean square error, mean absolute error and coefficient of determination $\left(\mathrm{R}^{2}\right)$ of the calibrated model were found to be about $3.86 \mathrm{~m}^{3} \mathrm{~s}^{-1}, 2.55 \mathrm{~m}^{3} \mathrm{~s}^{-1}$ and $95 \%$, respectively.

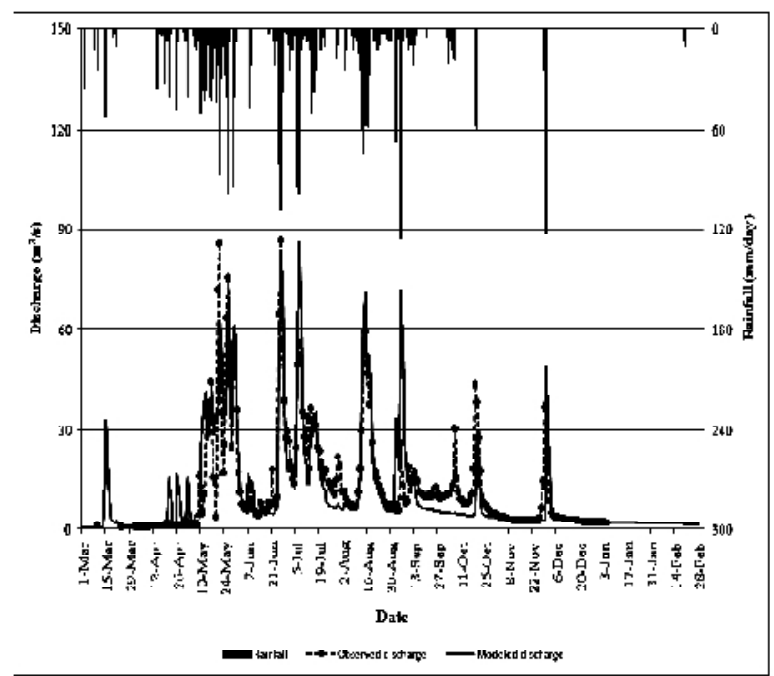

Figure 3: Observed discharge at Matiganj and rainfall at Srimangal along with calibrated discharge using the tank model

\subsection{STREAM TEMPERATURE}

Using the output, discharge, of the tank model, the velocity and depth of flow of the Lungla River at Motiganj were estimated. Assuming different $\mathrm{T}_{0}$, $\mathrm{T}_{\mathrm{e}}$ and $\mathrm{k}$ for different months, the daily water temperature at Motiganj was calibrated using equation (3). The length of the Lungla River, which is about $45 \mathrm{~km}$, is taken as the distance $x$ between the upstream section and downstream Motiganj. Equilibrium temperature for a month was considered to be linearly related with air temperature of that month (Caissie et al., 2005). The parameters were estimated such that the sum of squared errors between the observed and calibrated temperatures is minimized. The estimated parameters along with the average monthly air and water temperatures are given in Table 2. A time series plot of the measured and estimated water temperatures is shown in Figure 4. It is seen from the figure that the estimated temperatures follow the observed pattern of water temperatures quite well except for the months of July and August. If we had allowed initial and equilibrium temperatures to vary on a weekly basis instead of monthly as suggested in Bogan et al. (2003), we could obtain a better fit. As we had measured water temperature data for only one year (May 1995 to April 1996), we did not attempt a weekly calibration to avoid large parameter uncertainty.

Table 2: Observed air and water temperatures along with calibrated initial and equilibrium temperatures and heat exchange coefficient $(k)$

\begin{tabular}{|c|c|c|c|c|c|}
\hline Month & $\begin{array}{c}\text { Air } \\
\text { temp } \\
\left.\text { ( }{ }^{\circ} \mathrm{C}\right)\end{array}$ & $\begin{array}{l}\text { Water } \\
\text { temp } \\
\left(^{\circ} \mathrm{C}\right)\end{array}$ & $\begin{array}{l}\text { Initial } \\
\text { temp } \\
\left(^{\circ} \mathrm{C}\right)\end{array}$ & $\begin{array}{c}\text { Equilib } \\
\text {-rium } \\
\text { temp }\end{array}$ & $\begin{array}{c}k \\
\left(\begin{array}{l}W^{-2} \\
\left.K^{-1}\right)\end{array}\right.\end{array}$ \\
\hline Jan & 18.02 & 19.14 & 21.27 & 103 & 2.7 \\
\hline Feb & 20.51 & .94 & .93 & 110 & 2.7 \\
\hline Mar & 25.39 & 24.76 & 5.80 & 86 & 0.8 \\
\hline Apr & 27.84 & 28.05 & 28.56 & 100 & 3.8 \\
\hline May & 29.25 & 29.88 & 28.09 & 108 & 4.2 \\
\hline Jun & 28.42 & 28.02 & 25.30 & 114 & 3.6 \\
\hline Jul & 28.17 & 27.34 & 26.00 & 97 & 3.7 \\
\hline Aug & 28.41 & 27.84 & 28.03 & 92 & 3.6 \\
\hline Sep & 28.53 & 28.60 & 28.90 & 97 & 3.5 \\
\hline Oct & 28.11 & 28.42 & 28.39 & 105 & 3.1 \\
\hline Nov & 24.55 & 26.26 & 28.18 & 105 & 3.9 \\
\hline Dec & 19.66 & 21.59 & 21.59 & 105 & 3.4 \\
\hline
\end{tabular}

Note: ${ }^{1}$ as a percentage of air temperature 


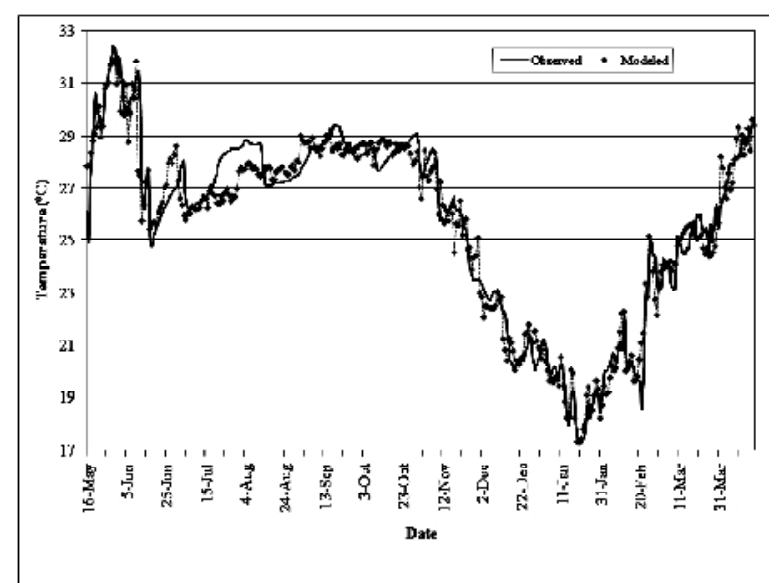

Figure 4: Observed and modeled water temperatures for the period of May 1995 to April 1996 at Motiganj on the Lungla River

\subsection{SEDIMENT LOAD}

We estimated the suspended sediment concentration of the Lungla River at Motiganj using equations (4) to (7). The estimated sediment flux is given in Figure 6. We had five sets of measured suspended sediment and Nephelometric turbidity unit (NTU) readings (not shown) in September 2000, which is around $500 \mathrm{~g} \mathrm{~m}^{-3}$ (i.e. $200 \mathrm{ppm}$ ). The corresponding flux is $0.0002 \times 80 \mathrm{~m}^{3} \mathrm{~s}^{-1}$ (maximum level in Figure 3) $\times$ $86400=1382 \mathrm{~m}^{3}$ day $^{-1}$. This was safely within the estimated volume flux of sediment. The simulated sediment concentrations from January to December were found to be about 244, 231, 380, 545, 2501, 2904, 2250, 1864, 1604, 1161, 436 and $413 \mathrm{~m}^{3}$ day $^{-1}$, sequentially, with an annual average of about 1217 $\mathrm{m}^{3}$ day $^{-1}$.

The Hail Haor in which the Lungla River discharges has a water area of about $30 \mathrm{~km}^{2}$. Dividing the sediment yield with the haor area, we obtain a sediment thickness of about $14.7 \mathrm{~mm}$. With a porosity of $40 \%$, the average height of sediment deposits over the lake bed is found to be about $24.5 \mathrm{~mm}$ per annum with a standard deviation of $8.8 \mathrm{~mm}$. There is some qualitative evidence of such siltation in the haor areas, although no quantitative information is available. It is to be noted that the BWDB measures sediment load in the rivers of
Bangladesh and the organization has no recorded data for the Lungla River and, as such, we could not make a rigorous calibration of the sediment routine. Furthermore, an average uniform sedimentation over the lake bed is assumed discounting spatial variation. Furthermore, the haor basin is still under the process of subsidence.

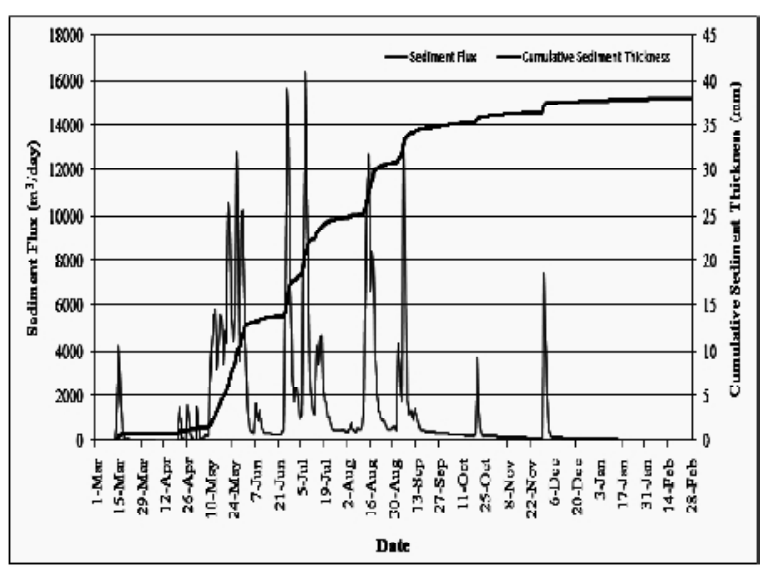

Figure 5: Estimated sediment flux at Motiganj of the Lungla River and predicted cumulative sediment thickness at the Hail Haor for a period of March 1988 to February 1989

\section{THERMAL STRATIFICATION AND BUOYANCY FLUX}

\subsection{THERMAL STRATIFICATION}

Air and water temperatures in a vertical array in the Hail Haor were recorded hourly during 199596 by using six temperature sensors equipped with an automatic data acquisition system. The sensors were placed at one meter vertical interval: $0.3 \mathrm{~m}$, $1.3 \mathrm{~m}, 2.3 \mathrm{~m}, 3.3 \mathrm{~m}, 4.3 \mathrm{~m}$ and $5.3 \mathrm{~m}$ above the haor bottom. Thus, the number of sensors recording water temperatures varied with the water level in the haor. Depth of water in the haor was also recorded hourly with a water level gauge. The details of the data collection system are given in Oka et al. (1997). A window of the measured temperature and water depth for the period of July to October in the monsoon season is given in Figure 6. 


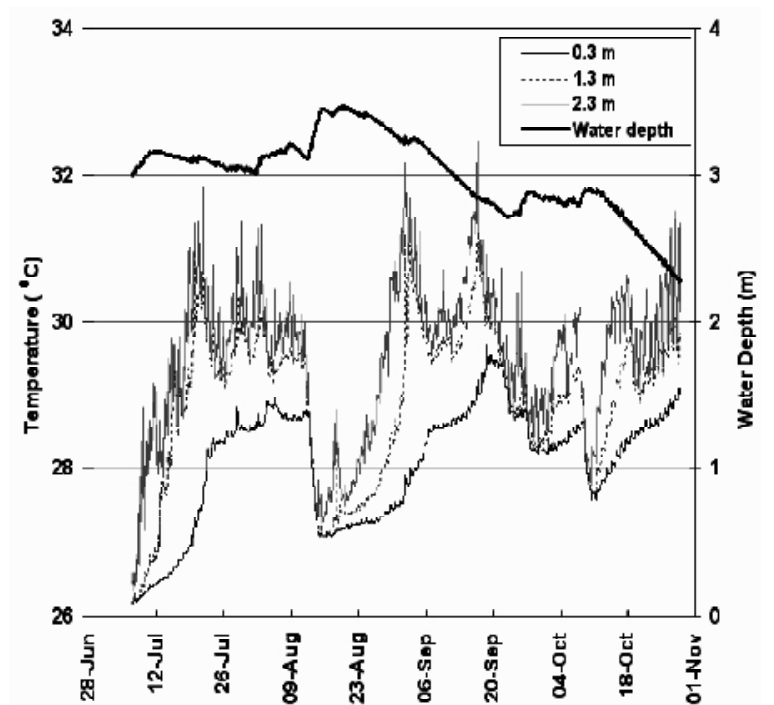

Figure 6: Measured water temperatures and water depth at the Hail Haor (the numbers in the legend indicate the vertical distance of the temperature sensors in meter from the haor bottom)

It is seen from the figure that the water temperatures vary over a range of about $7{ }^{\circ} \mathrm{C}$ in the summer monsoon - the variation in temperatures closer to the water surface is higher than that closer to the bed. Thermal stratification occurs in the haor during sunny and calm weather conditions. However, large flash floods cause destratification of the thermal regime and complete mixing of the water column. Such de-stratification occurred about 4-5 times in the monsoon of 1995. De-stratification due to flash floods lasts only for a couple of days. An important feature of the haor thermal behavior is that water temperatures decrease largely during the flood and recover to the equilibrium level after several days. Haor water in the event of a large flood is cooled by the on-rush of cool rainfall-runoff, latent heat transfer (evaporation), thermal conduction and back radiation in absence of solar radiation (Okubo, 1997).

\subsection{ADVECTION FLUX}

The advection flux is given by:

$$
A=\frac{G_{0}}{\Delta t} \quad \text { with } \quad G_{0}=\alpha g \Delta T_{1} h
$$

where $\Delta T_{1}$ is the temporal change in the bottom temperature in the vertical temperature profile. We estimated the advection flux for the Hail Haor and it is found to vary between $-4 \times 10^{-7}$ and $+4 \times 10^{-7} \mathrm{~m}^{2}$ $\mathrm{s}^{-3}$. The advection flux is found to be sensitive to flash flooding. The absolute magnitude of the flux is higher during the flood period. However, the hourly fluctuation of this flux is found to be lower during the flood period compared with the pre- and post-flood period fluctuations. This is because of the stability of the thermal stratification during high flow regime on sunny days. It thus appears that the river advection is not very important in the case of Hail Haor during high flow regime under calm weather.

\subsection{BUOYANCY FLUX}

Total buoyancy in a water column can be obtained by integrating the local buoyancy:

$$
G(z)=\int_{\alpha}^{z} \alpha g \delta T d \zeta
$$

where $\alpha=$ coefficient of thermal expansion of water; $\delta T=$ vertical temperature difference from the bottom sensor reading.

The rate of temporal change in total buoyancy is the vertical buoyancy flux. Such flux at a height of $\mathrm{z}$ from the lake floor can be calculated as:

$B(z)=\frac{\Delta G(z)}{\Delta t}$

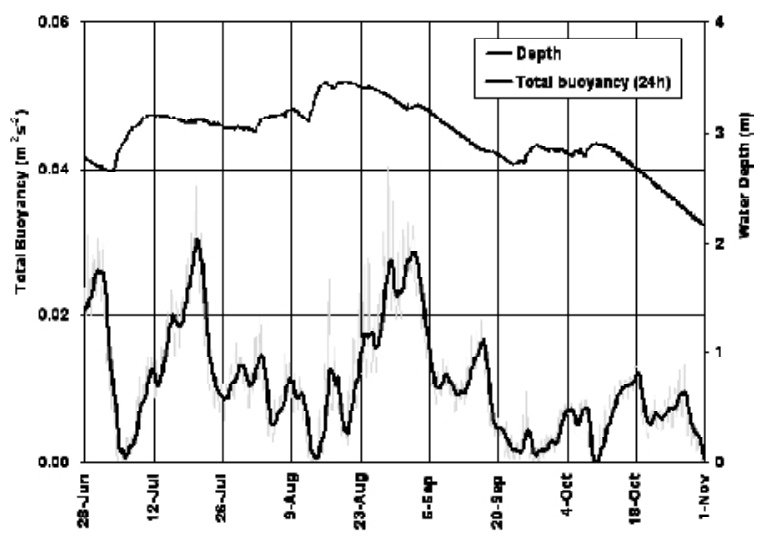

Figure 7: Estimated total buoyancy (hourly) during the monsoon season of 1995 at the Hail Haor (the yellow line is the raw data before moving average) 
Figure 7 shows the estimated total buoyancy along with the water depth during the monsoon of 1995. It is seen from the figure that the flash floods correspond to reduced total buoyancy as a result of thermal de-stratification.

We estimated this flux at the free water surface for the Hail Haor and smoothed out using a 24point moving average to suppress random fluctuations in hourly data. The estimated buoyancy flux during the monsoon of 1995 is shown in Figure 8 along with the total buoyancy and advection flux. The buoyancy flux does not contain the temporal change in the bottom temperature for the reference density and such change is taken into account as a horizontal advection flux using equation (8). Negative buoyancy flux in the figure indicates cooling of the haor water and positive flux indicates heating.

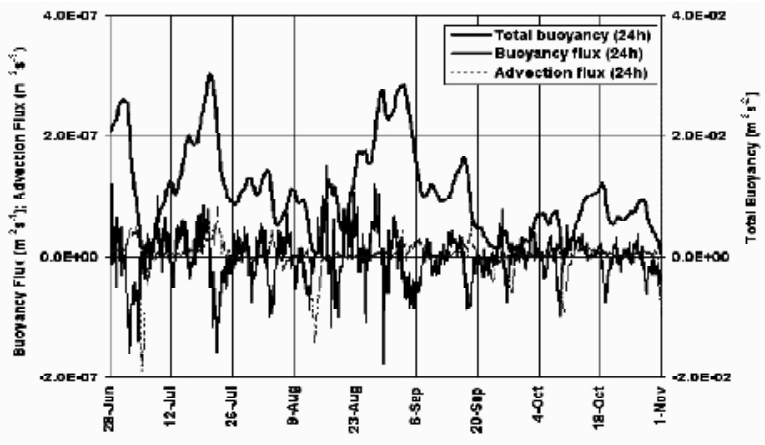

Figure 8: Estimated buoyancy and advection fluxes during the monsoon season of 1995 at the Hail Haor

\subsection{HEAT FLUX}

Heat flux $H$ can be estimated from the buoyancy flux $B$ using the following equation (Imboden, 2003):

$H=\frac{\alpha g B}{c \rho}$

We estimated the heat flux of the Hail Haor using the data of 1995-96. The flux was then smoothed out using a 24-point moving average filter to reduce the noise in the hourly data. It was found that the heat flux in the Hail Haor varies between -550 and $+500 \mathrm{~W} \mathrm{~m}^{-2}$ depending on date and time of the day.

Journal of Hydrology and Meteorology, Vol.6, No. 1

\subsection{RICHARDSON NUMBER}

Richardson number due to thermal stratification is given by the ratio of total buoyancy to friction velocity. It can be estimated by the following equation:

$R_{i}=\frac{g^{\prime} h}{u_{*}^{2}}$

We estimated $R_{i}$ using friction velocity of the Lungla River. The energy slope was assumed to be constant and equal to the river bed slope. Thus, the friction velocity depends only on the flow depth of the inflowing river. $R_{i}$ for the monsoon season of 1995 is given in Figure 9. Also shown in the figure is the ratio of the buoyancy flux to advection flux. It is seen from the figure that when water level rises fast in the event of a flash flood. Thermal de-stratification occurs, $R_{i}$ falls rapidly. Thus, during the flood period, $R_{i}$ works well as a stability parameter for the haor being related with flash floods. The higher fluctuations in the values of $R_{i}$ towards the dry season are due to lower friction velocity in the inflowing river. This tendency can be confirmed by looking at the buoyancy to advection flux ratio as the ratio is lower during the dry season. It is seen from the figure that the buoyancy flux is also sensitive to flash flooding. The flux is lower during the flood period compared to the pre- and post-flood periods. It was found that, the buoyancy flux varies between $-4 \times 10^{-7}$ and $+4 \times 10^{-7}$ $\mathrm{m}^{2} \mathrm{~s}^{-3}$ depending on the date and time of the day.

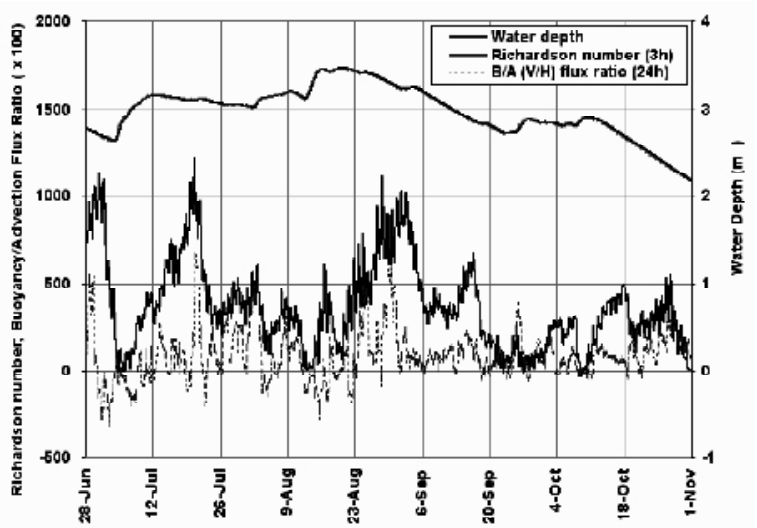

Figure 9: Hourly variation of water depth, Richardson number and the ratio of buoyancy to advection fluxes during the monsoon season of 1995 at the Hail Haor 


\section{CONCLUSION}

The processes of sedimentation and thermal stratification in relation to flash floods in the Hail Haor of the North-East Bangladesh are studied. A coupled hydrologic-hydraulic modeling approach was followed to simulate the discharge, water temperature and sediment load of the Lungla River at the entrance of the haor. The hydrologic model used is the tank model having soil moisture and channel routing components, and rainfall and evapotranspiration inputs. The hydraulic routine is based on the concept of equilibrium temperature, regime theory, resistance laws and Rouse profile for sediment concentrations. It also uses the tank discharge as an input. It is found that water, temperature and sediment hydrographs can be successfully simulated using this coupled modeling approach. The simulation result reveals an average annual sedimentation of $25 \mathrm{~mm}$ in the Hail Haor, which is a seasonal lake.

Flash floods and climatic conditions (temperature, sunshine and wind) are found to have a strong influence on the thermal response of the haor. The measured temperatures in a vertical profile of the haor water show that thermal stratification occurs on sunny days under calm weather during the summer monsoon. Due to flash floods, such stratification breaks down and a complete thermal mixing in the water column takes place. The estimated buoyancy flux shows that the absolute maximum value of the flux is about $4 \times 10^{-7} \mathrm{~m}^{2} \mathrm{~s}^{-3}$ and the flux is lower during the cooling period in the event of floods and lack of sunshine. The advection flux has large negative values and the Richardson number falls rapidly in the event of flash floods. It thus appears that the Richardson number and different fluxes are closely related to flash floods.

\section{ACKNOWLEDGEMENTS}

This research was carried out at the Graduate School of Environmental Science of Okayama University, Japan. The financial support provided to the first author during his stay in Japan under the UNESCO Chair program for Education for Sustainable Development is gratefully acknowledged. We thank the anonymous reviewers for their valuable comments and suggestions which helped improve the quality of the paper.

\section{REFERENCES}

Bogan, T., O. Mohseni, H.G. Stefan, 2003. Stream temperature-equilibrium temperature relationship. Water Resources Research 39(9), SWC 7-1-7-11.

Caissie, D., M.G Satish, N. El-Jabi, 2005. Predicting river water temperatures using the equilibrium temperature concept with application on Miramichi River catchments (New Brunswick, Canada). Hydrological Processes 19, 2137-2159.

Celik, I., W. Rodi, 1985. Mathematical modeling of suspended sediment transport in open channels. Proc. $21^{\text {st }}$ IAHR Congress, pp. 533-538.

Franchini, M., M. Pacciani, 1991. Comparative analysis of several conceptual rainfallrunoff models. Journal of Hydrology 122, 161-219.

Huang, W., K. Nakane, R. Matsuura, T. Matsuura, 2007. Distributed tank model and GAME reanalysis data applied to the simulation of runoff within the Chao Phraya River Basin, Thailand. Hydrological Processes 21, 2049-2060.

Imboden, D.M., 2003. The motion of lake waters. In: The Lakes Handbook: Limnology and Limnetic Ecology (ed. by O'Sullivan, P.E., C.S. Reynolds), Vol. 1, pp. 115-152, Blackwell Publishing.

Kato, T., 2005., Development of a water quality tank model classified by land use for nitrogen load reduction scenarios. Paddy Water Environment 3, 21-27.

Kerssens, P.J.M., A. Prince, L.C. van Rijn, 1979. Model for suspended sediment transport. Journal of Hydraulics Division 105(HY5), 461-476. 
Lee, Y.H., V.P. Singh, 2005. Tank model for sediment yield. Water Resources Management 19, 349-362.

Mizumura, K., 1995. Runoff prediction by simple tank model using recession curves. Journal of Hydraulic Engineering 121(11), 812-818.

Nagasaka, A., F. Nakamura., 1999. The influences of land-use changes on hydrology and riparian environment in a northern Japanese landscape. Landscape Ecology 14, 543-556.

Oka, T., K. Okubo, K. Yamakawa, K. Mori, M.A. Miah, A.F.M. Saleh, M. Salehin, 1997. Establishment of apilot systemfor acquisition of hydrologic data. Japan Bangladesh Joint Study Project on Floods, Topic 2: Investigation of the Mechanism of Flash Floods, Final Report, pp. 12-52, BUET and JICA.

Okubo, K., 1997. Annual flooding process forming haors, the seasonal lakes in the Northeast Bangladesh and their thermal responses. Japan Bangladesh Joint Study Project on Floods, Topic 2: Investigation of the Mechanism of Flash Floods, Final Report, pp. 144-153, BUET and JICA.
Paik, K., J.H. Kim, H.S. Kim, D.R. Lee, 2005. A conceptual rainfall-runoff model considering seasonal variation. Hydrological Processes 19, 3837-3850.

Sugawara, M., 1979. Automatic calibration of the tank model. Hydrological SciencesBulletin 24(3), 375-388.

Sugawara, M., 1995. Tank model. In: Computer models of watershed hydrology (ed. by Singh, V.P.). pp. 165-214, Water Resources Publications, Baton Rouge, LA.

Sugawara, M., I. Watanabe, E. Ozaki, Y. Katsuyama, 1984. Tank model with snow component. Research Note No. 65, National Research Center for Disaster Prevention, Kyoto, Japan.

Tsujimoto, T., 1986. Sediment transport in turbulent flow: On diffusion coefficients of suspended sediment (in Japanese). Proc. Annual Conference on Hydraulics 30, 637-642,JSCE. 